\title{
FORMALDEHYDE HEALTH HAZARDS AND ITS
} PRECARCINOGENIC EFFECTS

\author{
By \\ ${ }^{1}$ Zayet HH, ${ }^{1}$ Lotfy BM, ${ }^{2}$ Sabry DA, ${ }^{3}$ Mohamed OE, ${ }^{1}$ Said RM \\ ${ }^{1}$ Department of Occupational and Environmental Medicine, ${ }^{2}$ Department of Medical Biochemistry and \\ Molecular Biology, Faculty of Medicine, Cairo University. ${ }^{3}$ Human Cytogenetics, National Research Center.
}

\begin{abstract}
Introduction: Formaldehyde (FA) is a high-production-volume chemical with a wide array of uses. Recently, it was re-evaluated for its carcinogenic effects and reclassified as humans carcinogen (Group 1) based on sufficient evidence in human and experimental animal studies. Aim of the work: to evaluate the pre-carcinogenic effects of formaldehyde among medical personnel in The Histopathology Laboratory. Materials and Methods: The study was conducted in histopathology laboratory including 30 workers occupationally exposed to formaldehyde and 29 persons matching with the exposed group for age, sex and socioeconomic status with no history of occupational exposure to formaldehyde. A questionnaire was done including inquiries about age, sex, occupational history and special habits. All participants were subjected to the following laboratory investigations: measuring DNA protein crosslink (DPC) and protein 53 (p53) both mutant and wild type. Results: This study shows statistically significant increase in symptoms and signs of respiratory and eye and skin irritation with significant increase of DPC and p53 wild and mutant types as pre carcinogenic effects of formaldehyde. Conclusion: The studied group in the histopathology laboratory was exposed to formaldehyde level above the exposure limits recommended by NIOSH, ACGIH and OSHA with adverse health effects in the form of increase in DPC and p53 (wild and mutant types) which are considered to play an important role in the carcinogenesis of FA.
\end{abstract}

Key words: Formaldehyde, Environmental monitoring, DNA protein crosslink (DPC), Protein 53(p53) 


\section{Introduction}

Formaldehyde (FA) is a highproduction-volume chemical with a wide array of uses (Ladeira et al., 2011). Recently, it was re-evaluated for its carcinogenic effects and reclassified as human carcinogen (Group 1) based on sufficient evidence in human and experimental animal studies (IARC, 2006).

FA is genotoxic and mutagenic to mammalian cells and the primary DNA alterations induced by FA are DNA protein crosslinks (DPCs) as a primary genotoxic effect (Lu et al., 2010).

DNA-protein cross-links (DPCs) are unique among DNA lesions in their unusually bulky nature. The steric hindrance imposed by crosslinked proteins (CLPs) will hamper DNA transactions, such as replication and transcription, posing an enormous threat to cells (Toshiaki et al., 2009).

Human protein 53 (p53)is a tumor suppressor protein that induces or represses the expression of a variety of target genes involved in cell cycle control, senescence, and apoptosis in response to oncogenic or other cellular stress signals (Joerger and Fersht, 2008).

Inactivation of the p53 tumor suppressor is a frequent event in tumorigenesis. In most cases, the p53 gene is mutated giving rise to a stable mutant protein whose accumulation is regarded as a hallmark of cancer cells. Mutant p53 proteins not only lose their tumor suppressive activities but often gain additional oncogenic functions that endow cells with growth and survival advantages. Interestingly, mutations in the p53 gene were shown to occur at different phases of the multistep process of malignant transformation, thus contributing differentially to tumor initiation, promotion, aggressiveness and metastasis (Rivlin et al., 2011).

Aim of the work: to evaluate the precarcinogenic effects of formaldehyde among medical personnel in The Histopathology Laboratory.

\section{Materials and Methods}

- Study design: It is a descriptive cross sectional study.

-Place and duration of study: The study was carried in the histopathology laboratory at Kasr Al-Aini Hospital, 
Cairo University, from June 2011 to may 2013.

-Study sample: The studied population comprised 30 persons occupationally exposed to formaldehyde, 12 pathologists, 12 technicians and 6 workers with age ranges 22 to 55 years and a control group of 29 persons, randomly selected from other lab in kasr Al Aini hospital matching the exposed group for age, sex and socioeconomic status with no history of occupational exposure to formaldehyde. The exposure duration was calculated by multiplying weekly working hours in a year with years of employment.

\section{- Study methods}

The studied population was subjected to

1-A self designed questionnaire including inquiries about age, sex, occupational history and special habits.

2-Clinical examination.

3- Environmental monitoring was done in different places of the Histopathology laboratory using a portable Formaldemeter. The sites of monitoring covered all possible exposure areas including corridors, sites of receiving the specimen, place of microscopic examination of the specimen, trimming and preparation of the specimens for microscopic examination.

\section{4- Laboratory investigation}

$4-5 \mathrm{ml}$ of peripheral blood sample was collected in heparinized syringe under complete aseptic condition and mixed gently to prevent clotting. Blood lymphocytes were isolated by a standard Ficol/sodium protocol and subjected to DNA extraction and qPCR for wild and mutant p53 and DNA/protein crosslink assessment using Hochest fluorescent dye.

\section{1- DNA protein crosslinks (DPC)} (Quievryn and Zhitkovich, 2000).

DPC were assessed in isolated lymphocytes using K-SDS assay. In this method DNA fragments containing covalently attached proteins were selectively precipitated in the presence of $\mathrm{KCl} / \mathrm{SDS}$. Cells or DNA/histone mixtures were lysed in $1 \%$ SDS, cellular lysates were sheared by passing through $21 \mathrm{G}$ needles and DPC were 
precipitated by addition of $200 \mathrm{mM}$ $\mathrm{KCl}$. Dependence of DNA precipitation on the presence of attached proteins was verified by elimination of $\mathrm{KCl} / \mathrm{SDS}$ precipitable DNA by pre-treatment of samples with $0.2 \mathrm{mg} / \mathrm{ml}$ proteinase $\mathrm{K}$ for $1 \mathrm{~h}$ at $37^{\circ} \mathrm{C}$ prior to crosslink analysis. $0.1 \mu \mathrm{g} / \mathrm{ml}$ of Hoechst dye 33258 was added and DPC was measured as a percent $(\%)$ in the presence of $0.5 \mu \mathrm{M}$ Hochest in a multi well fluorescence reader.

\section{2-Quantitative Real-Time PCR} to measure quantity of wild and mutant p53:

Real-time PCR was assessed to estimate quantity of wild and mutant p53 genes. We used a step one for quantitative real-time PCR. Exon 8 of the p53 gene was amplified separately by incubating on a step one (Applied Biosystem) for $10 \mathrm{~min}$ at $94^{\circ} \mathrm{C}$ for initial denaturation followed by 35 cycles at $94^{\circ} \mathrm{C}$ for $30 \mathrm{~s}, 55^{\circ} \mathrm{C}$ for $30 \mathrm{~s}$, and $72^{\circ} \mathrm{C}$ for $1 \mathrm{~min}$. The final extension step was $72^{\circ} \mathrm{C}$ for $7 \mathrm{~min}$. The standard reaction mixture $(25 \mu \mathrm{L})$ contained 100 ng of genomic DNA, $0.25 \mu \mathrm{mol} / \mathrm{L}$ of each primer and SYBR green reagent supermix. All PCR reactions were performed in sets of four. The means of the specific gene DNA and GAPDH DNA copy numbers were calculated for each patient separately, and relative quantitation ratios were generated (Venkat et al., 2009).

\section{Statistical analysis}

Data was coded and analyzed using the statistical package SPSS version 16 . The mean values, standard deviation (SD), median and ranges were estimated for quantitative variables, as for the qualitative variables, the frequency distribution was calculated. Comparisons between exposed and control groups were done using Chi Square $\left(\chi^{2}\right)$ test for qualitative variables and using the independent simple t-test for normally distributed quantitative variable. Analysis of variance (ANOVA) test was done between different categories of the exposed group. The non-parametrical Mann-Whitney test was used for quantitative variables not normally distributed. P-values less than 0.05 were considered statistically significant.

\section{Consent:}

Authors declare that a verbal consent 
was taken from the studied group and consent from pathology department before making the environmental study. Confidentiality was maintained.

\section{Ethical approval}

The study protocol was approved by Occupational and Environmental Department Ethical Committee, Faculty of Medicine, Cairo University.

\section{Results}

Environmental monitoring revealed that the higher level of FA was present at the site of formaldehyde disposal (mean \pm SD $2.04 \pm 1.3 \mathrm{ppm}$ ) followed by the site of tissue processor after its opening (mean \pm SD $1.81 \pm 0.76 \mathrm{ppm}$ ) where technicians are working. The lower level was observed at the site of receiving and trimming the specimen (mean \pm SD $0.66 \pm 0.21$ and $0.87 \pm$ 0.24 respectively) done by pathologists followed by the site of cut section using microtone (mean \pm SD $0.42 \pm 0.02 \mathrm{ppm})$ and corridor (mean \pm SD $0.42 \pm 0.16$ ppm) where technicians and workers were present. The results obtained from the environmental study of our work were found to exceed the exposure limit recommended by NIOSH $(0.016$ ppm), OSHA Permissible Exposure Limit (OSHA PEL) (0.75ppm) for the 8-hour Time- Weighted Average (TWA) and ACGIH ceiling limit (0.3ppm) (ATSDR, 2008).

There was no significant difference in the demographic characteristics between the exposed and control groups. But there is a significant statistical difference between different subgroups of the exposed as regards smoking habits being more prevalent among technicians.

As for the effects of smoking, there are no significant statistical effects of smoking on DNA protein crosslinks and p53 (both wild and mutant types) but there is statistical significant increase of p53 (wild type) among non smokers when compared to smokers. 
Table (1): Frequency distribution of health hazards of formaldehyde on the exposed group compared to the control group.

\begin{tabular}{|c|c|c|c|c|c|c|}
\hline Group & $\begin{array}{r}\text { Expo } \\
\text { No }\end{array}$ & $\begin{array}{l}\text { group } \\
\%\end{array}$ & $\begin{array}{l}\text { Cor } \\
\text { No }\end{array}$ & $\begin{array}{l}\text { 9) } \\
\%\end{array}$ & $\chi^{2}$ & P value \\
\hline $\begin{array}{l}\text { Respiratory system } \\
\text { Nasal irritation } \\
\text { Throat irritation } \\
\text { Dyspnea } \\
\text { Cough and expectoration } \\
\text { Wheezes }\end{array}$ & $\begin{array}{r}11 \\
26 \\
11 \\
19 \\
6\end{array}$ & $\begin{array}{l}36.7 \\
86.7 \\
36.7 \\
63.3 \\
20.0\end{array}$ & $\begin{array}{l}0 \\
0 \\
1 \\
1 \\
0\end{array}$ & $\begin{array}{l}0.0 \\
0.0 \\
3.4 \\
3.4 \\
0.0\end{array}$ & $\begin{array}{r}13.07 \\
44.93 \\
10.04 \\
23.60 \\
6.45\end{array}$ & $\begin{array}{l}0.000 * * \\
0.000 * * \\
0.002 * \\
0.000 * * \\
0.011 *\end{array}$ \\
\hline $\begin{array}{l}\text { Skin } \\
\text { Red skin } \\
\text { Scaly dermatitis } \\
\end{array}$ & $\begin{array}{l}6 \\
1 \\
\end{array}$ & $\begin{array}{r}20.0 \\
3.3 \\
\end{array}$ & $\begin{array}{l}1 \\
1\end{array}$ & $\begin{array}{l}3.4 \\
3.4\end{array}$ & $\begin{array}{c}3.86 \\
0.001\end{array}$ & $\begin{array}{l}0.049^{*} \\
\text { n.s. }\end{array}$ \\
\hline $\begin{array}{l}\text { Eye } \\
\text { Eye irritation }\end{array}$ & 30 & 100 & 0 & 0.0 & 59.0 & $0.000 * *$ \\
\hline $\begin{array}{l}\text { Adverse reproductive } \\
\text { outcome } \\
\text { Miscarriage } \\
\text { Congenital anomalies }\end{array}$ & $\begin{array}{l}6 \\
1\end{array}$ & $\begin{array}{r}20.0 \\
3.3\end{array}$ & $\begin{array}{l}3 \\
0\end{array}$ & $\begin{array}{c}10.3 \\
0.0\end{array}$ & $\begin{array}{c}1.06 \\
0.983\end{array}$ & $\begin{array}{l}\text { n.s. } \\
\text { n.s. }\end{array}$ \\
\hline
\end{tabular}

*: Significant $(\mathrm{P}<0.05)$

**: Highly significant $(\mathrm{P}<0.005)$

n.s.: non-significant $(\mathrm{P}>0.05)$.

This table shows highly significant difference between exposed and control groups as regards respiratory, skin and eye symptoms ( $\mathrm{P}$ value $<0.05$ ), while no significant difference was found for adverse reproductive outcome between both groups. 
Table (2): Frequency distribution health hazards of formaldehyde of the exposed subgroups .

\begin{tabular}{|c|c|c|c|c|c|c|c|c|}
\hline \multirow{2}{*}{$\begin{array}{l}\text { Clinical } \\
\text { parameters }\end{array}$} & \multicolumn{2}{|c|}{$\begin{array}{l}\text { Pathologists } \\
\quad(n o=12)\end{array}$} & \multicolumn{2}{|c|}{$\begin{array}{l}\text { Technicians } \\
\quad(n o=12)\end{array}$} & \multicolumn{2}{|c|}{$\begin{array}{c}\text { Workers } \\
(\text { no }=6)\end{array}$} & \multirow[t]{2}{*}{$\chi^{2}$} & \multirow[t]{2}{*}{ p value } \\
\hline & & $\%$ & No & $\%$ & & $\%$ & & \\
\hline $\begin{array}{l}\text { Respiratory system } \\
\text { Nose irritation } \\
\text { Throat irritation } \\
\text { Cough } \\
\text { Dyspnea } \\
\text { Wheezes }\end{array}$ & $\begin{array}{l}4 \\
12 \\
3 \\
0 \\
0\end{array}$ & $\begin{array}{l}33.3 \\
100 \\
25.0 \\
0.0 \\
0.0\end{array}$ & $\begin{array}{r}5 \\
8 \\
11 \\
8 \\
5\end{array}$ & $\begin{array}{l}41.7 \\
66.7 \\
91.7 \\
66.7 \\
41.7\end{array}$ & $\begin{array}{l}2 \\
6 \\
5 \\
3 \\
1\end{array}$ & $\begin{array}{c}33.3 \\
100 \\
83.3 \\
50.0 \\
16.7\end{array}$ & $\begin{array}{l}0.215 \\
6.92 \\
12.77 \\
12.05 \\
6.56\end{array}$ & $\begin{array}{l}\text { n.s. } \\
0.031 * \\
0.002 * * \\
0.002 * * \\
0.038 *\end{array}$ \\
\hline $\begin{array}{l}\text { Eye } \\
\text { Eye irritations }\end{array}$ & 12 & 100 & 12 & 100 & 6 & 100 & --- & --- \\
\hline $\begin{array}{l}\text { Skin symptoms } \\
\text { Red skin } \\
\text { Scaly dermatitis }\end{array}$ & $\begin{array}{l}0 \\
0\end{array}$ & $\begin{array}{l}8.3 \\
0.0\end{array}$ & $\begin{array}{l}4 \\
1\end{array}$ & $\begin{array}{r}33.3 \\
8.3\end{array}$ & $\begin{array}{l}1 \\
0\end{array}$ & $\begin{array}{r}16.7 \\
0.0\end{array}$ & $\begin{array}{l}2.39 \\
1.55\end{array}$ & $\begin{array}{l}\text { n.s. } \\
\text { n.s }\end{array}$ \\
\hline $\begin{array}{l}\text { Adverse } \\
\text { reproductive } \\
\text { outcome } \\
\text { Miscarriage } \\
\text { Congenital anomalies }\end{array}$ & $\begin{array}{l}4 \\
0\end{array}$ & $\begin{array}{l}33.3 \\
0.0\end{array}$ & $\begin{array}{l}1 \\
1\end{array}$ & $\begin{array}{l}8.3 \\
8.3\end{array}$ & $\begin{array}{l}1 \\
0\end{array}$ & $\begin{array}{r}16.7 \\
0.0\end{array}$ & $\begin{array}{l}2.39 \\
1.55\end{array}$ & $\begin{array}{l}\text { n.s. } \\
\text { n.s. }\end{array}$ \\
\hline
\end{tabular}

n.s.: Non-significant $(\mathrm{P}>0.05)$

This table shows significant statistical difference between subgroups as regards respiratoy symptoms $(\mathrm{P}<0.05)$ except for nose irritation symptoms. No significant difference for skin, eye irritation and adverse reproductive outcome between subgroups of the exposed group ( $p>0.05)$. 
Table (3): DNA-protein crosslinks (DPC) and pre carcinogenic parameters (p53 wild and p53 mutant types) of exposed and control groups.

\begin{tabular}{|l|c|c|c|c|}
\hline \multicolumn{1}{|c|}{ Parameters } & $\begin{array}{c}\text { Exposed } \\
\text { Group }(\mathbf{n = 3 0}) \\
\text { Mean } \pm \text { SD }\end{array}$ & $\begin{array}{c}\text { Control } \\
\text { Group (n=29) } \\
\text { Mean } \pm \text { SD }\end{array}$ & t test & P value \\
\hline DPC & $4.18 \pm 3.34$ & $0.70 \pm 0.27$ & 5.58 & $0.000^{* *}$ \\
\hline P53 (wild type) & $1.29 \pm 0.43$ & $0.40 \pm 0.22$ & 9.89 & $0.000^{* *}$ \\
\hline P53 (mutant type) & $1.62 \pm 0.65$ & $0.52 \pm 0.24$ & 8.50 & $0.000^{* *}$ \\
\hline
\end{tabular}

**Highly significant $(\mathrm{P}<0.005)$.

This table shows statistical significant difference between exposed and control as regards DPC and pre-carcinogenic parameters including p53 wild type and p53 mutant type.

Table (4): Analysis of variance (ANOVA) for duration of exposure, DPC, SCE, Mn and $p 53$ wild and mutant types among the different categories of exposed group $(n=30)$.

\begin{tabular}{|c|c|c|c|c|c|c|}
\hline \multicolumn{2}{|c|}{ Parameters } & $\begin{array}{c}\text { Pathologists } \\
(\mathbf{n = 1 2})\end{array}$ & $\begin{array}{c}\text { Technicians } \\
(\mathbf{n = 1 2})\end{array}$ & $\begin{array}{c}\text { Workers } \\
(\mathbf{n = 6})\end{array}$ & f test & P value \\
\hline DPC & $\begin{array}{c}\text { Median } \\
\text { Range }\end{array}$ & $\begin{array}{c}2.65 \\
1.50-14.30\end{array}$ & $\begin{array}{c}3.20 \\
1.50-12.70\end{array}$ & $\begin{array}{c}3.20 \\
1.40-11.70\end{array}$ & 10.22 & n.s. \\
\hline $\begin{array}{c}\text { P53 (wild } \\
\text { type) }\end{array}$ & $\begin{array}{c}\text { Median } \\
\text { Range }\end{array}$ & 1.40 & 1.18 & 1.41 & 25.09 & n.s. \\
\hline $\begin{array}{c}\text { P53(mutant } \\
\text { type) }\end{array}$ & $\begin{array}{c}\text { Median } \\
\text { Range }\end{array}$ & $\begin{array}{c}1.37 \\
0.55-2.74\end{array}$ & $0.73-2.63$ & $0.52-2.69$ & 35.11 & n.s. \\
\hline
\end{tabular}

n.s.: Non-significant $(\mathrm{P}>0.05)$.

The table shows no significant differences are found as regards DPC, Mn and p53 (wild and mutant type) among the different categories of exposed group. 
Table (5): Pearson correlation between DPC, and p53 (wild and mutant types) among workers exposed to formaldehyde in histopathology laboratory $(\mathbf{n}=\mathbf{3 0})$.

\begin{tabular}{|l|c|c|c|}
\hline \multicolumn{2}{|c|}{ Parameters } & $\begin{array}{c}\text { P53 } \\
\text { (wild type) }\end{array}$ & $\begin{array}{c}\text { P53 } \\
\text { (mutant type) }\end{array}$ \\
\hline DPC & r value & 0.034 & $0.000^{* *} 0.655$ \\
& p value & 0.858 & 0.05 \\
\hline
\end{tabular}

**Highly significant $(\mathrm{P}<0.005)$.

This tables shows significant correlations between DPC and p53 (mutant type) while no significant correlation was found between DPC and p53 (wild type).

\section{Discussion}

The results of environmental monitoring revealed that the higher measurements were obtained at the site of formaldehyde disposal (mean \pm SD $2.04 \pm 1.3 \mathrm{ppm}$ ) followed by the site of tissue processor after its opening (mean \pm SD $1.81 \pm 0.76 \mathrm{ppm}$ ) where technicians are working. The lower measurements were observed at the site of receiving and trimming the specimen (mean \pm SD $0.66 \pm 0.21$ and $0.87 \pm$ 0.24 respectively) done by pathologists followed by the site of cut section using microtone (mean \pm SD $0.42 \pm 0.02 \mathrm{ppm}$ ) and corridor (mean \pm SD $0.42 \pm 0.16$ ppm) where technicians and workers were present. This is in agreement with the results obtained from the study done by Costa et al. (2011) in 5 hospital pathology laboratories who found that the main FA vapor emissions occurred during the macroscopic examination of FA-preserved specimens and during the disposal of specimens and waste solutions with formaldehyde levels ranging from $0.04-1.58 \mathrm{ppm}$.

Environmental results obtained in this study was found to exceed the exposure limit recommended by NIOSH (0.016 ppm), OSHA Permissible Exposure Limit (OSHA 
PEL) (0.75ppm) for the 8-hour Time Weighted Average (TWA) and ACGIH ceiling limit (0.3ppm) (ATSDR, 2008).

The studied population comprised 30 medical and paramedical personnel exposed to formaldehyde in histopathology laboratory and 29 as a control group. The exposed group was divided into 3 subgroups (pathologists, technicians and workers) with duration of employment between 2-22 years. No significant differences were found between the exposed and control groups as regard age, gender and smoking habits but significant difference was found for smoking habit between different categories of the exposed group being more among technicians.

As regards the results of history taking and clinical examination, our study showed highly significant increase of eye, nose and throat irritation symptoms among the exposed group when compared with the control group while no significant differences were found between the exposed subgroups for eye and nose irritation (table 1,2). These results agreed with Lang et al., (2008) who exposed human volunteers to formaldehyde concentrations relevant to the workplace and noted that the exposed persons complaints of ocular and nasal irritation at levels of $0.3 \mathrm{ppm}$ while the signs of eye irritation was observed at a level of $0.5 \mathrm{ppm}$ with a peak of $1 \mathrm{ppm}$. Our results disagree with the results of Mueller et al., (2013) who found that formaldehyde concentrations of $0.7 \mathrm{ppm}$ for $4 \mathrm{~h}$ and $0.4 \mathrm{ppm}$ for $4 \mathrm{~h}$ with peaks of $0.8 \mathrm{ppm}$ for $15 \mathrm{~min}$ did not cause adverse effects related to irritation and no differences between hypo and hypersensitive subjects were observed.

The potential of formaldehyde to produce chronic respiratory tract disease remains a controversial issue. Our study showed significant increase of respiratory symptoms (cough, dyspnea and wheezes) among exposed group compared to the control group with significant increase of respiratory symptoms among technicians (table 1, 2). This may be due to their exposure to high concentration of formaldehyde in the working areas.

These are similar to the study done by Neghab et al.,(2011) at a local melamineformaldehyde resin producing plant and found higher prevalence rates of regular 
cough, wheezes, shortness of breath, chest tightness and episodes of chest illness associated with cold among exposed workers to formaldehyde. Similarly, Rahimifard et al., (2013) and Saad et al., (2006) showed that the exposed medical staff from pathology laboratories had high prevalence rates of regular cough, wheezes, itching and burning sensations of the nose on acute exposure to formaldehyde and these effects were higher with the increase in the duration of exposure.

In addition to respiratory and eye irritation, our results showed statistically significant increase of skin irritation symptoms among exposed group compared to the control group while no significant differences were found between different categories of the exposed group. These results resemble those of Lundov et al., (2010) who found that his studied population developed formaldehyde-allergy from their personal products containing formaldehyde.

Formaldehyde's teratogenecity and its effects on human reproduction are still a matter of scientific controversy. There is limited evidence that formaldehyde causes adverse reproductive effects. The risk of developmental defects to the exposed fetus ranges from none to minimal. There have been reports of menstrual disorders in women occupationally exposed to formaldehyde but they are controversial (IARC, 2004 and Tang et al., 2009). Our results showed no significant statistical difference of adverse reproductive outcome between the exposed and control group which is against the results of Duong et al., (2011) who found an increased risk of spontaneous abortion and adverse pregnancy outcomes in formaldehydeexposed women.

As regards gastrointestinal system, it was reported that ingestion of solutions of formaldehyde is not likely to be a significant route of occupational exposure. Much of the data related to the adverse effects of oral ingestion of formaldehyde in humans are from case reports of acute poisoning incidents (Li and Song, 2006 and Yanagawa et al., 2007). Similarly our study showed no significant statistical difference of gastrointestinal symptoms between the exposed and control groups. 
$\mathrm{Lu}$ et al., (2010) showed that FA is genotoxic and mutagenic to mammalian cells and the primary DNA alterations induced by FA are DNA protein crosslinks (DPCs) as a primary genotoxic effect. Our results showed highly significant increase of DPC among exposed personnel to formaldehyde compared to the controls (table 3). Similar results were found by Shaham et al., (2003) who concluded that exposure to formaldehyde causes the formation of DPC in human peripheral white blood lymphocytes and that assay is sensitive enough to discriminate between exposed and unexposed workers. As well Sameer and his colleagues (2012) found an increased level of DNA damage in peripheral blood lymphocytes of medical staff exposed to formaldehyde in histology, anatomy and pathology laboratories and this DNA damage originate from DNA single-strand breaks, repair of DNA double-strand breaks, DNA adduct formation or DNA-DNA and DNAprotein cross links.

Recently, formaldehyde was reevaluated for its carcinogenic effects and reclassified as "Carcinogenic to humans (Group 1)" based on sufficient evidence in human and experimental animal studies (IARC, 2006).

One of the most common somatic genetic alterations in human cancers involves the loss of inhibitory function of the p53 tumor suppressor gene (Rivlin et al., 2011).

Our results showed highly significant increase in both wild and mutant p53 proteins among exposed group with increase of wild type p53 among females than males. Also a significant positive correlation was found between DPC and mutant p53 proteins (table 5). These are similar to the results of Shaham et al., 2003 who found that exposure to FA increases the risk of having a higher level of pantropic p53. The same study showed a significant positive correlation between the increase of pantropic p53 protein and mutant p53 protein with the risk of having higher levels of pantropic p53 was determined mainly by levels of DPC. But Saad and his colleagues (2006) found no significant difference in p53level among exposed and control group. Therefore, the studied population are at increased risk 
of developing cancer because of the increase of p53level especially mutant type which are considered to play an important role in the carcinogenesis of FA.

Conclusion and recommendations: The studied group in the histopathology laboratory was exposed to formaldehyde level above the exposure limits recommended by NIOSH, ACGIH and OSHA with adverse health effects in the form of increase in DPC and p53 (wild and mutant types) which are considered to be a key events in formaldehyde carcinogenesis. So we recommend the use of P53 especially mutant type as screening test in annual periodic examination for early detection of cancer. Regular health education and training of workers about health hazards of formaldehyde and the benefit of safe work practices is mandatory. Encourage the use of personal protective equipments. Regular environmental monitoring should not exceed the permissible exposure limits.

\section{References}

1. Agency for Toxic Substances and Disease Registry (ATSDR) (2008): Medical management guidelines for formaldehyde. Department of health and human services. Atlanta, Georgia,USA.
2. Costa S, Pinaa C, Coelhoab P, Costa C, Silvaa S, Portoc B, Laffond B and Paulo J (2011): Occupational exposure to formaldehyde: genotoxic risk evaluation by comet assay and micronucleus test using human peripheral lymphocytes. J Toxico Environ Health; 74 (1516): 1040-51.

3. Duong A, Steinmaus C, Cliona M M,Charles P Vand ZhangL (2011): Reproductive and developmental toxicity of formaldehyde: A systematic review. Mutat Res; 728(3): 118-38.

4. International Agency for Research on Cancer (IARC) (2004): IARC classify formaldehyde as human carcinogen. IARC monograph on formaldehyde.

5. International Agency for Research on Cancer (IARC). (2006):Formaldehyde, 2-butoxyethanol, and 1-tert-butoxy-2propanol. Monogr. Eval Carcinog Risks Hum volume88.

6. Joerger AC and Fersht AR (2007): Structural biology of the tumor suppressor p53 and cancerassociated mutants. Adv. Cancer Res; 97:1-23.

7. Ladeira C, Viegas S, Carolino E, Prista J, Gomes MC and Brito M (2011): Genotoxicity biomarkers in occupational exposure to formaldehyde. Mutat Res; 721(1):15-20.

8. Lang I, Bruckner T and Triebig G (2008): Formaldehyde and chemosensory irritation in humans: A controlled human exposure study. Regul Toxicol Pharmacol; 50 (1):23-36.

9. Li S and Song Z (2006): An incident of food poisoning in students caused by formaldehyde. Chin J Sch Health; 27(4):341.

10. Lu K, Ye W, Zhou L, Leonard BC et al. (2010): Structural characterization of formaldehydeinduced crosslinks between amino acids and deoxynucleosides and their oligomers. J Am Chem Soc; 132 (10): 3388-99.

11. Lundov MD, Johansen JD, Carlsen BC, Engkilde K,Menné T and Thyssen JP (2010): Formaldehyde exposure and patterns of concomitant contact allergy to formaldehyde and formaldehyde-releasers. Contact Dermatitis;63(1): 31-6. 
12. Mueller JU, Bruckner T and Triebig G (2013): Exposure study to examine chemosensory effects of formaldehyde on hyposensitive and hypersensitive males. Int Arch Occup Environ Health; 86(1):107-17.

13. Neghab M, Soltanzadeh A and Choobineh A (2011): Respiratory morbidity induced by occupational inhalation exposure to formaldehyde. Ind Health; 49(1):89-94.

14. Quievryn G and Zhitkovich A (2000): Loss of DNA-protein crosslinks from formaldehydeexposed cells occurs through spontaneous hydrolysis and an active repair process linked to proteosome function. Carcinogenesis; 21(8):1573-80.

15. Rahimifard $\mathrm{H}$, Heidari $\mathrm{H}$, Abbasinia M, Noruzi M, Mahdinia M, ArastY (2013): Respiratory Effects Induced by Occupational Exposure to Formaldehyde among Health Care staffI. JOH; 5: 26-30.

16. Rivlin N, Brosh R, Oren M and Rotter V (2011): Mutations in the p53 tumor suppressor gene important milestones at the various steps of tumorigenesis. Genes Cancer; 2(4): 466-74.

17. Saad A, Beshir S and Baathallah S (2006): Prediction of Respiratory Hazards, Cytotoxicity, and Carcinogenicity of Occupational Exposure to Formaldehyde in Pathology Laboratories. JASMR; 1 :(1).
18. Sameer MG, Elmesallamy GE and Mohamad MS (2012): Evaluation of genotoxic effects of formaldehyde in adult albino rats and its implication in case of human exposure.Life Sci J; 9(4): 3085 - 93.

19. Shaham J, Bomstein Y, Gurvich R et al., (2003): DNA-protein crosslinks and p53 protein expression in relation to occupational exposure to formaldehyde. Occup. Environ Med; 60:403409.

20. Tang X, Bai Y, Duong A, Smith MT, Li L and Zhang L (2009): Formaldehyde in China: production, consumption, exposure levels, and health effects.Environ Int; 35(8):1210-24.

21. Toshiaki N, Atsushi K, Mayumi M et al. (2009): Homologous recombination but not nucleotide excision repair plays a pivotal role in tolerance of DNA-Protein crosslinks in mammalian cells. J Biolo Chem; 284(40): 27065-76.

22. Venkat R, Katkoori, Xu J, Chandrakumar S, Wen W, Sreelatha M, Harvey B., William E. G. and Upender M. (2009): Prognostic Significance of p53 Codon 72 Polymorphism Differs with Race in Colorectal Adenocarcinoma. Clin Cancer Res; 15: 2406 - 16.

23. Yanagawa $\mathrm{Y}$, Kaneko N, Hatanaka K, Sakamoto T, Okada Y and Yoshimitu S (2007): A case of attempted suicide from the ingestion of formalin. Clin Toxicol (Phila); 45(1):72-6. 